\title{
Peripheralization and Catching Up in Eastern Europe in Historical Perspective*
}

\author{
Andrea Komlosy \\ University of Vienna \\ Hannes Hofbauer \\ University of Vienna
}

\begin{abstract}
Starting from the historical roots of Eastern European peripheralization and orientalization in the framework of the unfolding unequal division of labour in Europe since the $16^{\text {th }}$ century, the article is discussing concepts and trajectories of "catching-up" between 1867 and 2004. Both associative dependent integration with the world-economic cores and self-reliant national or regional integration can be observed. The evaluation departs from four historical moments, 1867 (Austro-Hungarian Compromise), 1918, 1945 and 1989 with an outlook on the new geopolitical dividing lines and alliances after the dissolution of Comecon 1991 and the beginning of EU-enlargement towards Eastern Europe in 2004. Strategies, successes and limits are discussed in front of the interest of Western powers and Russia as well as geopolitical moments and cycles, offering opportunities and restrictions for governments to improve their national economy and international performance. In spite of undeniable upgrading processes in some periods, catching-up has been overshadowed by four fundamental traps: the growth trap, the national trap, the debt trap and the militarization trap, occuring at specific moments of the process, allowing to identify cycles of catching-up. Finally, as catching-up has been reproducing dependency and peripheralization in new forms, the concept of catching-up has to be reconsidered.
\end{abstract}

\section{PARTICULARITY OF EASTERN EUROPE VERSUS HISTORY OF PERIPHERALIZATION}

According to the specialization in Western Sciences and of Western Scientists, Eastern European History represents a special discipline with a strong regional focus which allows carrying out certain focused reSocial Evolution \& History, Vol. 18 No. 1, March 2019 94-109 
search. However, it risks losing the connection with the rest of Europe and the rest of the world, although Eastern Europe has had a long tradition of inter-regional interaction with other world regions. While Western particularities became universalized, the developments in Eastern Europe are put on a different agenda: they deserve interest and research, but only as a particular problem, which does not follow the general pattern of development. They are analyzed whether and to which extent they fulfil, or lag behind Western Europe. Trapped in an asymmetric comparison, Eastern Europe is conceived weaker, delayed, backward, nourishing racist interpretations for its inferiority, and justifying Western expansion, conquest, or annihilation (Hofbauer 2007; Kappeler 2002). In a radical understanding, Eastern Europe is defined out of Europe; at the same time its 'orientalization' allowed considering Western Europe to represent the norm of 'civilization'. In comparison with nonChristian cultures, which were denied the potential to develop modern societies by their own efforts, Eastern Europe due to its Christianity was considered to be a part of the same 'universal family', a kind of younger brother, who has the potential to assimilate and catch-up with the West.

When mapping Eastern Europe one has to take account of shifting borders and shifting notions and connotations of 'East' and 'West'. It was not before the age of the Enlightenment, that the European 'North' was converted into 'Eastern Europe' (Wolff 1994). Only after the European cores had shifted north-west-wards, the equation of 'barbarism' with the 'North', rooted in Greek and Roman antiquity, was replaced by the 'East', thus separating 'Eastern Europe' from 'Europe'. This change of location reflects the endeavours of the North West European powers to identify Russian territorial aspirations even if they expressed the Russian wish to copy and to compete with Western patterns - with 'barbarism', or 'Asiatic despotism', attributed to tsarist absolutism, state communism, or post-communist oligarchic capitalism (Hofbauer 2016). The stigma of barbarism was not limited to Russia, however. In the view of contemporary Western politicians, philosophers, and travellers, since the eighteenth century the European East started, when the rivers Oder/Odra, Leitha or Drau/Drava were crossed, and it included Polish, Hungarian and Ottoman controlled territories, long before they became part of the 'Eastern Bloc' under Soviet dominance after World War II. With the exception of Yugoslavia and Albania, two other models of state socialism, Eastern Europe was united only when the Soviet Union, the hegemonic power which dominated the region beyond its state borders between 1945 and 1989/91, forged a sort of regional integration according to Soviet guide-lines (COMECON, Warsaw Treaty Organisation). When the 
Soviet bloc, as well as Yugoslav unity broke apart, Eastern Europe did not 'return to Europe', as many post-communist citizens and statesmen longed for. Eastern Europe experienced a re-translation of the political-ideological antagonism of the period of block confrontation into its previous 'otherness', based on the idea of Western superiority, imposed on Eastern Europe by economic, political, military, and cultural means.

Although Russia has always been part of Eastern Europe, it is - except for its hegemonic role - not part of our investigation. Russia differed and differs from the other Eastern European regions because of its imperial constitution, sheer size, number of inhabitants, and military power. The Eastern European regions were characterized by changing statehood, shifting external domination, and limited political sovereignty. Vast territories suffered occupation or annexation by - competing Great Powers, including the Russian Empire, which at the same time became itself economically dependent from Western Europe. Eastern Europe in our context means: the peripheral eastern parts of the Habsburg Monarchy (resp. its successor states Slovakia, Hungary, Slovenia, Croatia, partly Romania and Poland); so Bohemia, Moravia and the later Republic of Austria which were industrial centres of the Monarchy will not be included into the considerations. But we include Poland, which was partitioned between Prussia, Austria and Russia, as well as the Balkans (often referred to as 'South Eastern Europe') under Ottoman respectively Habsburg rule (Albania, Bosnia and Herzegovina, Bulgaria, Macedonia, Montenegro, Serbia, and partly Romania). This notion of Eastern Europe also includes the Baltic parts of the Tsarist Empire, Latvia, Estonia and Lithuania. So rather than on 'Eastern Europe', which also contains Russia and the European successor states of the Soviet Union, we focus on a 'Europe in between', squeezed between the ascending project of the EU-integration and the declining project of Soviet Union and Yugoslav disintegration. Shifting political positions among the countries waiting for the EU-membership have impacts on the composition of this region, which - in modification of Jenö Szücs' 'Three historical regions of Europe' (Szücs 1983) - can be considered a 'Third Europe' between East and West.

The regions, countries and inhabitants of this 'Europe in between' are located between three historical European spiritual centres: Rome Constantinople - Moscow. The latter exercised shifting and competing historical influence on the region, and they still shape the region, its external alliances and internal conflicts. Secularization only superficially replaced interference and attraction of these centres. In the case of Rome, there were new political centres, representing Catholic (com- 
promising with Protestantism because they failed to ban it) universalism: Paris, Vienna, and - since the political integration and the enlargement of the European Union - Brussels, where at the beginning of the twenty-first century the power of attraction is concentrated. Brussels outrivalled Istanbul (which took over the Byzantine heritage) and Moscow, which rejected Constantinople as a spiritual centre for Russian Orthodoxy after it had become the capital of the Ottoman Empire in 1453. After the Russian/Soviet Revolution the spiritual lead of Moscow was based on the communist ideology, its collapse did not only concern political integration, but also the attraction of Russia as a cultural centre.

One way of liberating Eastern European history from its enclosure within the dichotomy of European East-West comparison is to ask for interrelations with other parts of the world. From this perspective, the Eastern European regions show the characteristic features of peripherality in political or economic respects. Its 'orientalization' is based on the same pattern, which was applied for the Asian regions.

By using the concepts of world-system analysis the differences between regions can be translated into imbalances in regional development, which are embedded and thus can be explained within a system of unequal division of labour on an inter-regional or inter-national level. As a consequence, the peripheralization is not regarded as an exception, an anomaly, or a divergence: it is interpreted to be a necessary and characteristic feature of the process of capital accumulation, which depends upon the combination of different modes of production, forms and organisations of labour, and levels of income in different world regions, thus shaping cores and peripheries.

\section{ATTEMPTS TO CATCH UP WITH THE WEST}

According to the theoretical framework of the World-System theory (compare Chase-Dunn 1982; Hofbauer and Komlosy 2000; Nolte 1982; Wallerstein 1974-1989), Eastern Europe fulfilled and still fulfils peripheral functions in the capitalist world system, at least since the sixteenth-seventeenth centuries when the economic centres had shifted from Northern Italy and Southern Germany to the Atlantic coast. According to specific demands at specific time peripheral regions supply the core regions with raw materials, agricultural products, labour force, industrial capacities (e.g., extended work-benches, made-to-order-production) or military services (soldiers, buffer zones, military facilities). There is much historical evidence for the economic dependency of East European regions, unequal exchange and transfer of values allowing for the rise of North Western Europe to become a hegemonic core. However, to a certain extent, world-system analysts 
fell into the trap, set up by the invention of Eastern European unity in the age of the Enlightenment, which served to underline Western European 'civilization' to represent the universal standards of human development.

On the other hand, one can hardly deny the economic gap and the functional integration of the Eastern European regions into a Westernled world economy. There have always been attempts to overcome the peripheral status by catching-up efforts (Nolte 1991; Kappeler 2002; Komlosy 2012; Senghaas 1982). So Eastern Europe can be regarded as peripheral part of a modernization process which is centred in Western (and Central) Europe, which needs and creates peripheries. In this scenario Eastern Europe is part of the global 'South' and its deficiencies result from the underdevelopment caused by its peripheral integration into the unequal division of labour with the 'North', which in the case of Eastern Europe is situated in the 'West'. Conversely, from an Eastern European point of view the modernization can also be treated as aimed at overcoming the structural dependency from the North/West by establishing economic, political, and cultural developments controlled by local/regional interests. These attempts were embedded into the competition between the Great Powers of Western and Central Europe, the Russian and the Ottoman Empires (and their successors), for whom Eastern Europe did not only fulfil economic, but military and strategic functions as well.

We claim that catching-up modernization requires favourable economic, social, and political conditions; historical turning points to overcome peripheralization which depend on a coincidence of internal and external factors occurred in 1867, 1918, 1945, and 1989/91. Successful modernization is not so much depending upon a particular political system, but on a constellation of possible strength which allows the political regulation of the accumulation process in the interest of local/regional forces. Successes and failures are not only due to internal policy and measurements (development policies; internal blockages, e.g., lack of reform, lack of capital, deficiencies of markets, innovation, planning ...); at the same time they depend on shifts in economic conjunctures (e.g., from an expanding to a recessive cycle), and a changing global situation.

\section{POINTS OF DEPARTURE FOR CATCHING UP MODERNIZATION}

To illustrate our arguments we take examples from various Eastern Europe states and regions. The time frame is marked by the Dual Settlement of the Habsburg Monarchy (1867) and the accession of eight 
Eastern European states to the European Union (2004). The focus is on a long term comparative perspective, trying to relate political and economic cycles with specific historical events, shaping historical periods and turning points:

1867-1914/18: Period of the Austro-Hungarian Dual Settlement or Compromise;

1918-1939: Interwar period of new state sovereignty;

1938-1945: Period of German expansion and association with Nazi

Germany;

1945-1989: Period of socialist catching-up under Soviet hegemony;

1989ff: Period drawing new lines along Western interests polarizing different regions, or 'nations' according to their ability for integration with the West.

1867

There were earlier examples of new states aiming to overcome the integration with their former colonial power, the Ottoman Empire, like Serbia (1830) or Romania (1856). In their cases the focus was on the establishment of independent political institutions, while economic dominance was already exercised from Western and Central Europe, when the Ottomans were still in power; dependency from the West could hardly be tackled, as these powers were considered to guarantee state sovereignty vis-à-vis the Ottoman Empire. So we open the period of catching-up of former internal colonies with the case of Hungary. In 1867 as a consequence of the 'Dual Settlement' (Compromise), Hungary gained quasi independence from the Austrian Habsburg State. Both states were united by a personal union and common institutions in the field of foreign policy, foreign trade, and military affairs. The Hungarian government could now pursue national politics and at the same time profit from a strong ally in military affairs and the defence of its protectionist trade policies. There were undeniable successes in industrial development, build-up of infrastructure and industrial production, up-grading of exports and the improvement of various social indicators. However, catching-up was limited to a few extracting sectors, which span off processing capacities. It was limited to a few core regions, increasing the gap between urban and industrial centres and rural peripheries, which caused masses of impoverished agricultural labourers into migration. The success of catching-up relied on foreign debts and investments, in the first phase Austrian (and Bohemian) ones, which - step by step - were replaced by French and British ones, thus reflecting the competition among cores for the control of peripheries. Austria lost this race in Hungary to the Western banks and investors. 


\section{8}

With the breakup of the Habsburg, the Hohenzollern and the Romanov Empires in 1918, the number of independent states in the European periphery increased; the restructuring of the Balkan peninsula interstate borders gave rise to the new Kingdom of Serbs, Croats and Slovenes (SHS-Yugoslavia). The catching-up attempts in Eastern and South Eastern Europe met their limits very soon, however. In some states, the export oligarchies heavily contested reforms because they would undermine their traditional privileges, which they were granted by the former dynastic courts. Where reforms were carried out, they were confined by lack of capital and training, as well as the decline of prices and markets during the Great Depression of 1929/31. The following rapprochement of most Eastern European governments with Nazi-Germany was, on the one hand, inspired by the search for new export markets, and on the other hand, it was fuelled by the aspirations of national enlargement, which were cultivated in many states after the Peace Treaties of 1919/20.

\section{5}

The liberation from Nazi Germany opened another chance for the Eastern European countries to modernize state and economy. The geopolitical situation of the Soviet occupation, Western embargo and communist take-over opened the field for a catching-up model, which differed from the post-World War I situation. It was based on nationalization, state planning and the dominant role of a state party, on forced industrialization and a delinking from the Capitalist West, the Soviet answer to the involuntary delinking by the Western embargo policy. Instead of a strong intra-Comecon integration based on specialization and international division of labour, the priority was given to national industrialization and self-reliant economic structures in each individual state.

From a Western perspective the socialist model for a long time was only discussed in terms of political ideological premises, primarily if it was wishful to establish a socialist society, and secondly, if this aim was achievable and achieved by the Soviet type socialism. The East-West relations were a peculiar field of international politics, which were not at all related to the development discourse, which was limited to nonEuropean countries. Until today the development issues and 'Eastern Europe' are considered to be separate topics. Thanks to the global approach of the world-system analysis, the Soviet Union and Eastern Europe were finally integrated into the development discourse. This gave way to an evaluation of socialism as a means of catching-up development policy. As a result, the political and economic measure- 
ments of socialist planning and development were analysed as means to up-grade and to integrate peripheral Eastern Europe into the world economy; at the same time global economic changes were acknowledged to be decisive for the regional performance of Eastern European socialism (Frank 1977, 1992; Hofbauer and Komlosy 2000; Komlosy 2012). The increase of trade and financial relations, and in some cases of industrial cooperation, in the 1960s and 1970s, which marked a shift from import-substitution to debt-based, import-led growth, thus could be discussed in a broader framework, which was able to combine internal blockages of the socialist system with a new global paradigm. As a result of the new international division of labour, the core countries entered into post-industrial knowledge-based capitalism, while peripheries were integrated into the world economy to provide basic industrial assets and mass products. It follows that the world economic crisis of 1973/74 marked the transition for the socialist countries to fully reintegrate into the capitalist world economy; also in the Third World, import-substitution was replaced by new types of dependent integration. As long as the political and military alliances of Comecon and Warsaw Treaty Organization were operating and the Communist Parties controlled internal policy as well as external exchange, the socialist system seemed to be in power. The declining productivity, indebtedness, and growing social discontent about the gap in the living standard, which was more and more compared with the West, contributed to the opening of economy and society towards capitalist market elements, which contradicted and finally undermined political primacy.

\section{9/91}

The year 1989/91, when the socialist systems in Eastern Europe, the Soviet Union, Comecon and Warsaw Treaty Organization collapsed and the regional integration was replaced by informal capitalism and spontaneous westernization of those sectors and regions which could find markets and partners, can in no way be regarded as a point of departure for catching-up. It introduced a period which is characterized by enormous disintegration, bankruptcy, de-industrialization, loss of jobs, income, savings and social security, expressed by a decline in lifeexpectancy of 5 to 10 per cent in all Eastern European states except Czechoslovakia between 1989 and 1993 (UNICEF 1994: 35/36) - giving rise to the new technical term 'transition mortality.' At the beginning the threatening impacts of this decline were withhold or denied by the Western and Eastern propaganda, associating the end of socialism with the hope for a better future. Only after a while the Western public was warned of impoverishment and decline in Eastern Europe. The border control was established to replace the Iron Curtain in order to avoid the 
spread of social problems to the West. The Western public is still misled by the idea that Eastern Europe was facing the legacies of communism. This misinterpretation enabled Western media and governments to make up the take-over of markets, firms and labour, the degradation of skilled industries to cheap work-benches, as a strategy of relief. The Eastern Enlargement of the European Union, beginning in 2004, opened a new stage of polarization between Eastern and Western Europe, increasing the pressures on East European governments to comply with the requirements of the European Union core.

\section{LONG-TERM CONTINUITIES AND CHANGES}

The five periods between 1867 and 2004 represent continuity and change. There is continuity with regard to the overall aim to strengthen the economic structures on the regional/national level in order to improve the region's competitive position within the inter-regional division of labour. Conversely, the general decision if autonomy should be improved on political or on economic grounds, the internal orientation of economic politics and the external alignments show a great variety. The variation does not so much concern different regions and states; it is rather a variation between different periods, which each show a high correspondence between particular states. This strengthens the assumption that successes and failures to catch up depend upon a specific relationship between regional attempts and global conditions which are strongly shaped by world politics and the world economy. Thus, the five periods correspond to five cyclical shifts, each representing a catching-up cycle.

One has to distinguish periods more or less favourable for catchingup. Success and failures depend on politics carried out by national governments, and they depend on international conditions: on the one hand, on the character of economic conjuncture, that is a period of stability or crisis, or a period of expansion contraction; on the other hand - on the state of international relations, that is a period of peace and political stability or of turmoil, break-up of states and war. Successful catching-up does not necessarily rely on economic upswings and peaceful coexistence; in some cases such conditions favour catchingup, in other cases peripheral countries may profit from crises and conflicts in the core states opening up perspectives for peripheral states to improve their situation.

We can observe the following paths of development:

a) Associative dependent integration with the world economic centres, as it was and is on the agenda in the periods of 1867-1918 (for Eastern Europe except Hungary), 1939-1945 and 1989/2006ff, is 
an obstacle for self-reliant development. It serves the economic interest of the centres and of a small Eastern Europe elite cooperating with these centres (colonial type society). Peripheralization is inevitable. However, the roles the peripheries fulfil for the centres change according to economic and technological cycles. As there is no aim of selfreliant modernization, failure is not due to a trap, but rather predictable. Or, if one considers dependent integration as a means of catching-up, the trap lies in the idea of equal opportunities for cores and peripheries.

b) Self-reliant national and/or regional integration pursues a different path of development, rather counting on import-substitution, production for the domestic market, employment, education and skills allowing to exercise research and development and to supply export markets with processed goods. As a result of dependencia theory, which emphasized the peripheralizing effects of the relationship between cores and peripheries in the course of the latter's integration into the world economy, the de-linking and dissociative paths of development seemed to be viable to avoid the trap of peripheral integration. It was backed by historical investigations into the strategies of the leading industrial powers, which equally had relied on protectionism in order to develop industrial competiveness. Severing disadvantageous links with the former colonial power was a strategy pursued by a big number of East European and Third World states after decolonization and gaining independence. Under the conditions of global inter-dependency after 1973 unilateral de-linking of peripheral states turned out to promote isolation without development, hence opening a new debate on adequate strategies to combine dissociative with associative policies, strengthening self-reliance by new forms of regional integration.

\section{REALIZATION AND OBSTACLES TO CATCHING-UP DEVELOPMENT}

However, the claim for self-reliance does not necessarily lead to the desired results; it risks failing because of different restrictions. We can observe three periods when Eastern Europe undertook attempts to overcome peripheralization, namely: in 1867-1918 under the Dual Settlement in Hungary; in 1918-1939, and in 1945-1989. Why did these attempts (which showed temporary success) fail?

1) Growth trap/cyclical trap (1867-2006).

The Western model, which requires peripheries for its own success and therefore, creates, shapes and reproduces them; hence it cannot be simply transferred to a periphery with its economic structures oriented towards fulfilling specific functions for the centres. This ob- 
jection concerns capitalist industrialization, but it refers to socialist industrialization as well.

World capitalism (as well as all those who depend on it or strive to copy it or catch up with it) is characterized by economic cycles, when periods of expansion alternate with recession periods, the latter provoking a necessary adjustment for a new period of expansion. The adjustment to a new cycle is usually linked with a new regional, sectoral and technological pattern, which brings along changes of the interregional division of labour. The growth shifts to new industrial branches while pushing the old branches of growth into a marginal position. Hence, the regions that had concentrated to be competitive in those very branches (the very aim of catching-up), are driven aside and overtaken by new developments and innovations, in which they can only participate by taking over a dependent position again. So the cyclical innovation of capitalism reproduces the imbalances in regional development at each specific moment of history, trapping the peripheries' strive for catching-up like a vicious circle. It is very rare, that a periphery can profit from a cyclical shift.

2) National trap (1867-1945; 1989/9-2004).

The national trap may take several forms. The Hungarian government in the Dual Settlement period (1867-1918) claimed Madjar national hegemony over the non-Madjar parts of the country, hence provoking a resistance (against the Hungarian centre Budapest) which impeded the stabilisation of political autonomy within the Dual Habsburg Monarchy. So Austria and Hungary both became victims of the territorial break-up of the Monarchy. The new non-German and nonMadjar national states founded, or enlarged by new regions, in 1918 were also caught in a national trap. In the inter-war period they suffered from fragmentation, which rendered economic recovery and self-reliance more difficult. Nationalist ambitions prompted the cooperation with Nazi-Germany in which Eastern Europe fulfilled the role of a supplier of food, raw material and manpower for the war. Even the socialist period, which forced the Soviet satellites into the regional integration of Comecon, was blocked by ideas of national(ist) autarky, impeding a deeper economic integration of the socialist block. Today the permanent strive towards (nationalist) secession of those who hope to improve the pace of EU-integration by separating themselves from apparently - less developed parts of the state, opens the door for foreign political and economic influence on regional developments.

3) Debt trap (1867-1914; 1970-2004).

The indebtedness, on the one hand, results from lack of capital, which again results from the peripheral integration into the inter- 
regional/inter-national division of labour. On the other hand, it cannot be separated from the model of development, which can either count on internal resources or on foreign credit to enable the import of technologies and know-how. So the debt trap goes hand in hand with the growth trap. As long as exports find markets and allow paying the debt back, the model appears successful. With a shifting cycle, protectionist measurements, and new competitors debt-based catching-up may lead to a dead end. If the creditors raise the interest rates the trap is perfect.

Hungarian industrialization efforts in the last third of the nineteenth century relied on foreign capital, thus conflicting with the goal of national autonomy. The inter-war lack of capital, aggravated by the Great Depression, explains why most of the Eastern European states sought the cooperation with Nazi-Germany. After a period of delinking of the socialist block from the capitalist world (which on the one hand was imposed on the socialist states by the Western embargo policy, and on the other hand, was a reaction of the socialist states to pursue a socialist model of industrialization) between 1945 and 1970, the 1970s saw a shift from import-substitution to import-led growth, hence relying on credits which at the time of the world economic crises of post-1973 were cheaply available. When the interest rates were raised in 1980, it was only a question of time, when the debtors became caught in a debt trap, which ended the project of economic selfreliance first economically and then politically.

4) Militarization trap (1867-2004).

One must not forget the military factor which interfers into the success and failures of self-reliant paths of developments. Building up a self-reliant military sector may serve as a means of protection, and probably, it can be hardly avoided. At the same time militarization involves a state or alliance of states (block) into the arms race, which again - like the competition for growth rates - represents a trap, which is directed against the aim of the project itself. This happened in the Warsaw Treaty Organisation and the Soviet Union during the 1980s.

\section{NEW LINES OF PARTITION AFTER 1989/91}

After the collapse of Communism and the dismantling of the Iron Curtain, we face the establishment of new regional partition lines. Their geographical extension is shifting eastwards, along with the enlargement of Western influence over Eastern Europe. Constitutive for this period is on the one side the attractiveness of the European Union, on the other side - the weakness of Russia. As the enlargement of NATO, European Union (EU, Schengen Space, and Euro-Space), and World Trade Organization etc. is not synchronized, membership varies and 
territories and borders overlap. There is a competitive situation of accession - with regard to single candidate states as well as with regard to different agreements and alliances, allowing imposing far reaching conditions of accession not only upon new members, but on waiting applicants as well. The aspirants act against each other without considering the possibility of mutual support, regional coordination, or the setting up of conditions from their side. Their willingness to fulfil Western demands and requirements deserves special exploration.

Since the breakup of Comecon, Warsaw Treaty Organization and Soviet Union (1991) we face the enlargement of the European Union (Hofbauer 2007). The same applies to the enlargement of NATO. In ironical analogy to the 'permanent revolution' propagated by Leo Trotzky, one can in this case speak of 'permanent enlargement'. All Eastern European states are seized by this process, which is not restricted to formal membership. The European Union enlargement represents a sequence of required adaptions, which have to be fulfilled without time limit. Equally, the EU enlargement does not involve all aspirants at the same time, it advances step by step, confronting each single aspirant in bilateral talks with the European Union, allowing to impose the Aquis communitaire on each member state, thus creating a Europe of concentric circles, corresponding to the popular metaphorical expression of the 'Europe of different speeds'.

- The inner circle of the 15 elder members is surrounded by an outer circle of the ten new members of the 2004 enlargement.

- The next circle comprises the aspirants of 2004 (Romania and Bulgaria) and 2006 (Croatia, Macedonia and - with growing reservations in the meanwhile - Turkey).

- A small number of states, linked to the Union by Association Treaties, are hopeful to join the aspirant status soon, thus willing to open their markets, lower the cost of production, etc. (e.g., Serbia, Montenegro, Bosnia and Herzegovina ...)

- A number of states are in a waiting position; their future membership is not excluded; it is mentioned as a long-run perspective, thus contributing to an attitude, which makes them ready to fulfil any condition in order to approach membership. In this situation the split up of states according to their regional abilities to adapt to Western demands is a severe threat for state unity (for the break-up of states see the example of Czechoslovakia and Yugoslavia. With the separation of Serbia, Montenegro hopes to accelerate the rapprochement).

- Last but not least, there are European states beyond the reach of the present enlargement process. Future membership was denied to them - because of 'wrong' political performance (like Belarus, Uk- 
raine and Armenia), or extreme instability (like Albania and MoldovaTransnistria) at the time. There has been strong pressure on those states from the West, linked with promises of integration into Western military and economic alliances, if they severed the cooperation with Russia. Moldova and Georgia signed the European Partnership Agreement with the European Union in 2013, while Belarus and Armenia upheld strong ties with Russia and the Eurasian Customs Union. In the Ukraine, which also heavily relied on economic cooperation with Russia, the pressure gave way to the Maidan uprising, leading to a regime change and a close association with the European Union and the United States on the one side, provoking the dissociation of the Donbass and Crimea, backed by Russia, on the other side. Finally, Ukraine's dependent association with the West did not only undermine state unity, but promoted growing economic dependency from the West.

- In the case of Russia, membership is not taken into consideration. Conversely to the other Eastern European states, this applies for both the EU-European and the Russian side. Russia is considered and considers itself - as a Great Power, with a diminishing zone of influence, however.

After the collapse of the Soviet Union, there were several attempts of regional integration of the former Soviet Republics, involving all successor states with the exception of the Baltic republics, which joined the European Union in the first round of enlargement (Community of Independent States; Common Economic Space; GU(U)AMAssociation of Azerbaijan, Georgia, Moldova, Ukraine; Uzbekistan left in 2005; Eurasian Economic Community).

The mentioned projects are restricted to the territory of the former Soviet Union. The level of integration cannot be compared with the Western institutions, which compete with the Eastern projects in Eastern Europe and the states of the former Soviet Union, challenging their cohesion by political pressures as well as by competing offers. For instance, the refoundation of the GUAM in May 2006 was patronized by the USA - showing the competing aspirations to control the former Soviet republics in Eastern Europe and Central Asia.

As a result of the ongoing integrative attempts which overlap in those parts of Eastern Europe, which were part of the Soviet Union before 1991, a certain number of states are squeezed between the EUenlargement and post-Soviet offers of integration: Belarus, Ukraine, and Moldova-Transnistria (Hofbauer 2006). The lacking attractiveness of Russia as a partner for regional integration is not only due to the Eastern Enlargement of the European Union. The Russian weakness is also 
based on the missing perspective of development and integration for the former republics and neighbours. Neo-Russian economy relies on the production and export of energy and raw materials. By imposing prices, quantities and guaranties, it is able to blackmail the costumers without any offer for a common development (Krasilshchikov 2005).

With the collapse of the Soviet Union, 'Europe in between' had experienced a shift to the East. It was joined by former Soviet republics, whose situation is characterized by isolation and lacking perspectives of regional integration.

\section{PRELIMINARY CONCLUSIONS}

On a theoretical as well as on a practical level there is only one way out: the catching-up goal, which is imposed as a necessity by the core regions in order to keep the peripheries cooperating has to be overcome. Catching-up has to be replaced by a self-reliant development on the local, regional, and national levels as well as a trans-national integration on equal terms beyond the constraints of the hegemonic economic and political powers. The strategies of a self-reliant regional integration would have to be based on the following pillars: Economically local and regional markets would enjoy priority over export markets, local and regional production would gain priority over import-led growth and export orientation. Peaceful economic and political coexistence would allow nation states and supranational alliances to exercise a self-reliant currency policy, not allowing the U.S.-Dollar to make up for the indebtedness of the United States any more. Politically the priority for local and regional decision-making would go hand in hand with integration on equal terms, strengthening the local, regional, and national autonomy vis-à-vis the Great Enterprise and the Great Power interest to maintain an unequal division of labour.

\section{NOTE}

* A first draft of this paper war presented in June 2006 at the Institute for World Economy and International Relations (IMEMO) of the Russian Academy of Sciences in Moscow. It was published in Russian in: Mirovaja Ekonomika i mezhdunarodnye otnoshenija 2008, 4: 57-70; German translation in: Zeitschrift für Weltgeschichte 2009, 10 (2): 99-118.

\section{REFERENCES}

Chase-Dunn, Ch. (ed.) 1982 Socialist States in the World-System. Beverly HillsLondon-New Delhi: Sage.

Frank, A. G. 1977. Long Live Transideological Enterprise! The Socialist Economies in the Capitalist International Division of Labor. Review Fernand Braudel Center 1 (1): 91-140. 
Frank, A. G. 1992. Economic Ironies in Europe: A World Economic Interpretation of East-West European Politics. In Europe in the Making. Global and Regional Perspectives (= International Social Science Journal 131) Southampton: $41-56$.

Hofbauer, H. 2006. Mitten in Europa. Politische Reiseberichte aus BosnienHerzegowina, Belarus, der Ukraine, Moldawien-Transnistrien und Albanien. Wien: Promedia.

Hofbauer, H. 2007. EU-Osterweiterung. Historische Basis - ökonomische Triebkräfte - soziale Folgen. Wien: Promedia.

Hofbauer, H. 2016. Feindbild Russland. Geschichte einer Dämonisierung. Wien: Promedia; 2018: РОССИЯ ОБРАЗ ВРАГА. История одной демонизации. Krasnodar: Экоинвест.

Hofbauer, H. and Komlosy, A. 2000. Capital Accumulation and Catching-Up Development in Eastern Europe. Review Fernand Braudel Center 23 (4): 459-502.

Kappeler, A. 2002. Die Bedeutung der Geschichte Osteuropas für ein gesamteuropäisches Geschichtsverständnis. In Stourzh, G. (ed.), Annäherung an eine europäische Geschichtsschreibung (pp. 43-56). Wien: Verlag der Akademie der Wissenschaften.

Komlosy, A. 2012. Nachholende wirtschaftliche Entwicklung. Konzepte, Beispiele und Kriterien für Erfolg oder Scheitern. In Komlosy Andrea (ed.), Nachholende Entwicklung. Frankfurt am Main 2012, S. 11-42 (= Zeitschrift für Weltgeschichte 13.2).

Krasilshchikov V. 2005. An Experience of Russia as a Pattern of 'Negative Development' in the Condition of Globalization. Paper presented at EADI Conference, Bonn, 21-14 September. Working Group on Transformations in the World System - Comparative Studies in Development.

Nolte, H.-H. 1991. Tradition des Rückstands: ein halbes Jahrtausend 'Russland und der Westen'. In Vierteljahresschrift für Sozial- und Wirtschaftsgeschichte 78 (3): 344-364.

Nolte H.-H. 1982. The Position of Eastern Europe in the International System in Early Modern Times. Review Fernand Braudel Center 4 (1): 25-84.

Senghaas, D. 1982. Von Europa lernen. Entwicklungsgeschichtliche Betrachtungen. Frankfurt/Main.

Szücs, J. 1983. The Three Historical Regions of Europe. Acta Historica Academiae Scientiarium Hungaricae 29 (2-4): 131-184.

UNICEF 1994. Crisis in Mortality, Health and Nutrition. Regional Monitoring Report, no 2. Florence.

Wallerstein, I. 1974, 1980, 1989. The Modern World-System, vols. 1-3. New York - San Francisco - London: Academic Press.

Wolff, L. 1994. Inventing Eastern Europe: The Map of Civilization on the Mind of the Enlightenment. Stanford: Stanford University Press. 